UDC 628.19: 614.7

DOI: $10.21668 /$ health.risk/2019.2.05.eng

\title{
DRINKING WATER QUALITY: HEALTH RISK FACTORS AND EFFICIENCY OF CONTROL AND SURVEILLANCE ACTIVITIES BY ROSPOTREBNADZOR
}

\author{
N.V. Zaitseva ${ }^{1,2,3}$, A.S. Sboev $^{4}$, S.V. Kleyn ${ }^{1,2}$, S.A. Vekovshinina ${ }^{1}$ \\ ${ }^{1}$ Federal Scientific Center for Medical and Preventive Health Risk Management Technologies, 82 Monastyrskaya \\ Str., Perm, 614045, Russian Federation \\ ${ }^{2}$ Perm State University, 15 Bukireva Str., Perm, 614990, Russian Federation \\ ${ }^{3}$ Perm State Medical University named after Academician E.A. Wagner, 26 Petropavlovskaya Str., Perm, 614000, \\ Russian Federation \\ ${ }^{4}$ Informational methodical center, 19A Varshavskoe shosse, Moscow, 117105, Russian Federation
}

The paper dwells on issues related to quality of drinking water from centralized water supply systems; spotting out priority health risk factors; and assessing efficiency of control and surveillance activities performed by Rospotrebnadzor in the sphere of drinking water supply to the RF population.

It was detected that in most $R F$ regions control activities performed within social-hygienic monitoring mainly covered contents of substances belonging to the $3^{\text {rd }}$ and $4^{\text {th }}$ hazard categories in drinking water while contents of the $1^{\text {st }}$ hazard category substances were controlled only in several RF regions. The highest shares of samples exceeding hygienic standards as per contents of the $1^{\text {st }}$ hazard category substances were detected for such dangerous chemicals as chloroform, bromodichloromethane, trichloroethylene, 1,2-dichloroethane, tetrachloromethane, tetrachloroethylene, and arsenic.

Chlorine and chlorinated organic compounds, ammonium and chemicals that contain ammonium ion, iron, manganese, arsenic, nickel, and copper compounds, as well as microbiological contamination of water remain priority risk factors with the greatest contribution made into additional incidence associated with poor quality of drinking water taken from communal water supply systems. On average in the RF, in 2018 efficiency of Rospotrebnadzor activities estimated as per prevented GRP (gross regional product) losses caused by drinking water quality amounted to $70.1 \pm 10.1$ ruble per 1 ruble of costs. The highest values of the criterion were registered for the $3^{\text {rd }}$ cluster (67.7 ruble per 1 ruble of costs); the lowest ones, for the $1^{\text {st }}$ cluster $(47.4$ rubles per 1 ruble of costs).

Taking into account region peculiarities and different types of territories, it is necessary to develop specific regional programs and action plans aimed at preserving already obtained levels of population provision with qualitative drinking water, improving control and surveillance activities with wide implementation of risk-oriented approach, achieving targets fixed in national project and federal programs.

Key words: water supply, drinking water quality, risk factors, efficiency, control and surveillance activities.

High quality and safe drinking water should be available to everyone as it is greatly significant for a person's health, it is his or her basic right; it determines health and life quality of any nation ${ }^{1}$. According to the UN World Water Development Report ${ }^{2}$ published in 2019, more than 2 billion people worldwide don't have permanent access to pure drinking water and 844 million people have to spend at least half an hour a day to obtain some water or don't have any access to it at all. Even in Europe and North America about 57 million people don't have centralized water supply in their homes. According to WHO experts' es-

(c) Zaitseva N.V., Sboev A.S., Kleyn S.V., Vekovshinina S.A., 2019

Nina V. Zaitseva - Academician of the Russian Academy of Sciences, Doctor of Medical Sciences, Professor, Scientific Director (e-mail: znv@fcrisk.ru; tel.: +7 (342) 237-25-34; ORCID: https://orcid.org/0000-0003-2356-1145).

Aleksandr S. Sboev - Head, Chief Medical Officer in the Perm Krai (e-mail: urpn@59.rospotrebnadzor.ru; tel.: +7 (342) 239-35-63).

Svetlana V. Kleyn - Doctor of Medical Science, head of the department of methods for sanitary analysis and monitoring (e-mail: kleyn@fcrisk.ru; tel.: +7 (342) 236-32-64; ORCID: https://orcid.org/0000-0002-2534-5713).

Svetlana A. Vekovshinina - Head of Laboratory for conformity assessment techniques and consumer inspections (e-mail: veksa@fcrisk.ru; tel.: +7 (342) 237-18-04; ORCID: https://orcid.org/0000-0002-4833-0792).

${ }^{1}$ Drinking water quality guidelines: the $4^{\text {th }}$ edition [web-source] // World Health Organization. - 2017. - 628 p. - URL: https://www.who.int/water_sanitation_health/publications/dwq-guidelines-4/ru/ (date of visit June 18, 2019).

${ }^{2}$ Leaving No One Behind: The UN World Water Development Report 2019 [web-source] // World Health Organization. 2019. - URL: https://ru.unesco.org/node/305030 (date of visit June 18, 2019). 
timates $^{3}$, each dollar invested into improving drinking water quality, sanitation, hygiene, and water resources management brings 8 dollars as a return.

Despite a certain growth achieved in providing RF population with water corresponding to all safety requirements (by $1.97 \%$ in 2018 against 2014), in $201812.43 \%$ people in the country $(5.32 \%$ among urban population and $32.72 \%$, among rural one) were not provided with safe drinking water from centralized water supply systems ${ }^{4}$.

In 2018 in the RF approximately 16.1 thousand death cases (due to circulatory system diseases, digestive organs diseases, malignant neoplasms, certain infectious and parasitic diseases) and 1,764.49 thousand diseases in the digestive organs, urogenital system, musculoskeletal system and conjunctive tissue, circulatory system, skin and subcutaneous tissue, endocrine system and some other diseases were caused by drinking water that was contaminated with various chemicals (chlorine and chlorinated organic compounds, ammonia, iron, manganese, arsenic, nickel, copper, boron, magnesium, etc.) and microbe agents [1-5].

Rospotrebnadzor's organs and institutions bear the full responsibility for control over drinking water quality and providing sanitary- epidemiologic welfare of the population in the $\mathrm{RF}$; there are also some other state authorities that perform these functions within state sanitary-epidemiologic surveillance ${ }^{5}$, social-hygienic monitoring ${ }^{6,7}$, and industrial control ${ }^{8}$.

To provide population with high quality drinking water, including that coming from centralized water supply systems, is among priority state tasks that need to be solved in the Russian Federation.

The Federal Project "Pure water", which is a part of "Ecology" National Project ${ }^{10}$, stipulates a solution to a problem related to improving drinking water quality via modernization of water supply and water treatment systems with advanced technologies applied in the process.

The Federal Service for Surveillance over Consumer Rights Protection and Human Wellbeing (Rospotrebnadzor) and other participants in "Ecology" National Project are to solve the following vital tasks [6]: to increase a share of the RF urban population provided with qualitative drinking water from centralized water supply systems up to $99.0 \%$ by 2024 ; to provide $90.8 \%$ of the country population with qualitative drinking water from centralized water supply systems by 2024 .

These tasks can be solved only if Rospotrebnadzor's activities aimed at improving

\footnotetext{
${ }^{3}$ How does safe water impact global health? [web-source] // World Health Organization. - URL: https:// www.who.int/features/qa/70/ru/ (date of visit June 18, 2019).

${ }^{4}$ On sanitary-epidemiologic welfare of the population in the RF in 2017: The State report. - M.: The Federal Service for Surveillance over Consumer Rights Protection and Human Well-being, 2018. - $268 \mathrm{p}$.

${ }^{5}$ On approving the Administrative regulation on the state functions performed by the Federal Service for Surveillance over Consumer Rights Protection and Human Well-being in the sphere of conducting inspections over activities by juridical persons, private entrepreneurs and citizens in order to confirm these activities meeting all the requirements fixed in the sanitary legislation, RF legislation on consumers' rights, and rules for selling specific goods: The Order by Rospotrebnadzor dated July 16 , 2012 No. 764 (last edited on April 05, 2017) [web-source]. - URL: http://03.rospotrebnadzor.ru/content/223/7717/ (date of visit June 18, 2019).

${ }^{6}$ On organizing laboratory control during social-hygienic monitoring activities: The Letter by the Federal Service for Surveillance over Consumer Rights Protection and Human Well-being dated October 02, 2006 No. 0100/10460-06-32 [web-source] // MEGANORM: information system - URL: https://meganorm.ru/Index1/48/48489.htm (date of visit June 18, 2019).

${ }^{7}$ On approving regulations for conducting social-hygienic monitoring: The RF Governmental Order dated February $0, .2006$ года No. 60 (last altered on May 25, 2017) [web-source] // KODEKS: an electronic fund of legal and reference documentation. URL: http://pravo.gov.ru/proxy/ips/?docbody=\&prevDoc=102119943\&backlink=1\&\&nd=102104563 (date of visit June 18, 2019).

${ }^{8}$ SER 2.1.4.1074-01. Drinking water. Hygienic requirements to quality of water from centralized water supply systems. Quality control. Hygienic requirements to provision of hot water supply systems safety [web-source] // KODEKS: an electronic fund of legal and reference documentation. - URL: http://docs.cntd.ru/document/901798042 (date of visit June 18, 2019).

${ }^{9}$ Pure water: The Federal Project profile / approved by the record of the meeting by the "Ecology" national project design committee on December 21, 2018 No. 3 [web-source]. - URL: http://www.minstroyrf.ru/docs/17692/ (date of visit June 18, 2019).

${ }^{10}$ Ecology: The National Project profile / approved by the record of the RF Presidential Council on strategic development and national projects dated December 24, 2018 No. 16 [web-source]. - URL: https://ppt.ru/docs/pasport/210114 (date of visit June 18, 2019).
} 
drinking water quality become more efficient and productive; it includes control and surveillance activities based on a risk-oriented model for the Service functioning [7-10]. The latter involves concentrating efforts by Rospotrebnadzor on economic entities that deal with water collection, purification, and distribution as such entities can cause the greatest risks for population health in the $\mathrm{RF}$ regions $[11,12]$. A possibility to describe ultimate results of the activities performed by Rospotrebnadzor in terms of medical-demographic and economic parameters is truly vital for assessing their productivity and efficiency. All the abovementioned substantiated the necessity to conduct the given research.

Our research goal was to assess drinking water quality, to highlight priority health risk factors, and to assess efficiency of control and surveillance activities performed by Rospotrebnadzor's bodies in the sphere of providing $\mathrm{RF}$ population with drinking water.

\section{Data and methods}

Our research focused on drinking water quality parameters, as well as incidence and mortality in 85 RF regions in 2014-2018.

We performed hygienic assessment of drinking water quality as per chemical parameters using data provided by the Federal Information Fund for social and hygienic monitoring (FIF SHM) and a statistical report form No. 18 entitled "Data on sanitary situation in a RF region" collected over 2014-2018.

When assessing drinking water quality, we took into account drinking water quality criteria developed by Rospotrebnadzor in 2019 and outlined in the methodical guidelines MG 2.1.4.0143-19 ${ }^{11}$.

We assessed drinking water quality taking into account obligatory requirements fixed in the following sanitary regulations:
- HS 2.1.5.1315-03 "Maximum permissible concentrations (MPC) of chemicals in water objects used for drinking, communal and household purposes" (last revised on July 132017$)^{12}$.

- SER 2.1.4.1074-01 "Drinking water. Hygienic requirements to quality of drinking water taken from centralized water supply systems. Quality control. Hygienic requirements to providing safety of hot water supply systems" (last revised on April 2, 2018) ${ }^{13}$.

All the RF regions were classified (a type of each was determined) with a multi-dimensional statistical procedure, namely cluster analysis, as per a set of parameters that described efficiency and productivity of activities performed by Rospotrebnadzor as regards objects under surveillance dealing with water collection and purification and water distribution.

Cluster analysis was performed with a set comprising 8 parameters measured in 2014-2018 in $85 \mathrm{RF}$ regions:

- changes in the parameter "A share of population provided with qualitative drinking water from centralized water supply systems (\%)" in 2014-2018;

- changes in the parameter "Incidence among population caused by poor drinking water quality (cases per 1,000 people)" in 2014-2018;

- changes in the parameter "Population mortality caused by poor drinking water quality (cases per 1,000 people)" in 2014-2018;

- changes in the parameter "Frequency of violations concerning Clause 19, The Federal Law No. 52, in the sphere of "Water collection and purification" (\%)" in 2014-2018;

- changes in the parameter "Frequency of violations concerning Clause 19, The Federal Law No. 52, in the sphere of "Water distribution" (\%)" in 2014-2018;

- changes in the parameter "Incidence among population caused by poor quality

\footnotetext{
${ }^{11} \mathrm{MG}$ 2.1.4.0143-19. Guidelines on assessing increase in quality of drinking water taken from centralized drinking water supply systems / Approved by the RF Chief Sanitary Inspector on March 27, 2019. - M.: Rospotrebnadzor, 2019. - 10 p.

${ }^{12}$ HS 2.1.5.1315-03. Maximum permissible concentrations (MPC) of chemicals in water objects used for drinking, communal and household purposes [web-source] // KODEKS: an electronic fund of legal and reference documentation. - URL: http://docs.cntd.ru/document/901862249 (date of visit June 18, 2019).

${ }^{13}$ SER 2.1.4.1074-01 "Drinking water. Hygienic requirements to quality of drinking water taken from centralized water supply systems. Quality control. Hygienic requirements to providing safety of hot water supply systems" (last revised on April 2, 2018) [websource] // KODEKS: an electronic fund of legal and reference documentation. - URL: http://docs.cntd.ru/document/901798042 (date of visit June 18, 2019).
} 
drinking water quality that was prevented due to activities by Rospotrebnadzor (cases per 1,000 people)" in 2014-2018;

- changes in the parameter "Mortality among population caused by poor drinking water quality that was prevented due to activities by Rospotrebnadzor (cases per 1,000 people)" in 2014-2018;

- a ratio of gross regional product per capita in a RF region in 2017 to the same parameter in 2014 (inflation taken into account), times.

When assessing efficiency of control and surveillance activities concerning economic entities that dealt with water collection, purification, and distribution, we applied algorithms and procedures fixed in the Methodical Guidelines MR 5.1.0095-14 and some research works ${ }^{14}[13-20]$.

The methodology is based on comparing expenses borne by Rospotrebnadzor to perform control and surveillance to economic damage prevented due to lower incidence and mortality among population in a specific region. Here we determined economic damage caused by population incidence and mortality as production volumes (a part of gross regional product) that were not manufactured due to some employable population falling out of the production process. We determined losses caused by additional mortality that was associated with quality of the environment as per the following calculation: 0.5 year of being economically active per each death case; losses caused by additional incidence were calculated as 1 year of being economically active per each case. We took an average duration of each health disorder that made a person fall out of work being equal to half a calendar year $(\mathrm{L}=183)$ for each death case and to an average duration of temporary disability for each incidence case.

We calculated additional incidence cases and death cases among population caused by environmental factors and cases prevented by Rospotrebnadzor activities; to do that, we modeled relationships between environmental quality parameters, population health, and parameters of activities performed by Rospotrebnadzor in 2010-2017.

To calculate economic efficiency of control and surveillance functions performed by Rospotrebnadzor, we compared expenses on control and surveillance activities aimed at providing sanitary and epidemiologic welfare to prevented economic losses. All our calculations were based on data provided from state statistical reports including those obtained from the Form No. 1 entitled "Data on the results of state control (surveillance) and municipal control collected over 2018".

\section{Basic results}

According to data taken from the Form No. 18 entitled "Data on sanitary situation in a RF region", in 2018 authorities and bodies responsible for the federal state sanitary-epidemiologic surveillance over drinking water quality collected and examined more than 1,965.9 thousand water samples from centralized drinking water supply systems including:

- more than 361.1 thousand samples from centralized drinking water supply sources, more than 44.1 thousand of them taken from surface sources and more than 317.0 thousand samples taken from underground ones;

- more than 192.4 thousand water samples from water supply systems;

- more than 1,412.3 thousand water samples from distribution networks.

Quality control over drinking water from water supply systems (water from them is then directed into water distribution networks) revealed that in the RF obligatory requirements to sanitary and chemical parameters were more frequently violated in 2018 against 2014 (by $0.07 \%$ ) and their frequency amounted to $16.97 \%$. It could indirectly imply that implemented risk-oriented approaches to control and surveillance activities were more efficient than previously applied ones.

In 2018 water from centralized water supplied systems conformed to hygienic stan-

\footnotetext{
${ }^{14}$ MR 5.1.0095-14. How to calculate actual economic losses and those prevented due to control and surveillance activities as regards economic losses caused by population mortality, incidence, and disability associated with negative impacts exerted by environmental factors, approved by the RF Chief Sanitary Inspector on October 23, 2014. - M.: Rospotrebnadzor's Federal Center for Hygiene and Epidemiology, 2015 - 43 p.
} 
dards as per all sanitary and chemical parameters in Altai Republic, Mari El Republic, Kamchatka, and Tyva Republic; hygienic standards were violated in 44.92-69.9\% samples in the Khanty-Mansi Autonomous Area, Novgorod region, Ivanovo region, Kalmykia, and Dagestan.

A number of drinking water samples from centralized water supply systems that didn't correspond to hygienic standards as per microbiological and parasitological parameters decreased gradually over $2014-2018$ by $0.64 \%$ and $0.07 \%$ correspondingly. Regions where water quality as per microbiological parameters was the highest included Moscow city, Saint Petersburg, Sevastopol, Mari El Republic, Mordovia, Stavropol region, Kamchatka, Tambov region, Magadan region, and Chukotka Autonomous Area. 12.0-13.31\% samples taken in Jewish Autonomous Area, Smolensk region, Ingushetia, KarachayevoCherkesskaya Republic, and Primorye deviated from hygienic standards as per microbiological parameters.

As a whole, quality of drinking water supplied to population from centralized distribution networks improved in the RF. In 2018 a number of samples that deviated from hygienic standards as per sanitary-chemical parameters decreased by $2.47 \%$ against 2014 ; as per microbiological parameters, by $0.96 \%$. But there was a $0.04 \%$ increase in 2018 against 2014 in number of water samples taken from distribution networks that deviated from hygienic standards as per parasitological parameters.

In 2018 quality of drinking water taken from distribution networks was the highest as per sanitary-chemical parameters in Kamchatka, North Ossetia - Alania, Adygei, and Altai Republic (from 0.00 to $0.60 \%$ samples not conforming to standards). RF regions with the maximum (\%) share of water samples taken from distribution networks that didn't conform to sanitary requirements as per sanitary-chemical parameters included Novgorod region, Tver' region, Chukotka Autonomous Area, Karelia, and Kalmykia (from 34.89 to $58.31 \%$ samples not conforming to hygienic standards).
Less than $1 \%$ drinking water samples taken from centralized distribution networks didn't conform to hygienic standards as per microbiological parameters in Moscow city, Saint Petersburg, Kamchatka, Chukotka Autonomous Area, Adygei, Orenburg region, Novosibirsk region, Moscow region, Stavropol region, Tomsk region, Murmansk region, Voronezh region, Krasnodar region, and KhantyMansi Autonomous Area. All drinking water samples taken from centralized water distribution networks in Sevastopol in 2018 conformed to hygienic standards as per microbiological parameters.

In 2018 RF regions with the maximum (\%) share of drinking water samples taken from distribution network that didn't conform to sanitary-epidemiologic requirements as per microbiologic parameters included Chechen Republic, Dagestan, Jewish Autonomous Area, Ingushetia, and Karachayevo-Cherkesskaya Republic (from $9.45 \%$ to $23.90 \%$ samples deviating from hygienic standards).

As per data provided by the Federal Information Fund of Social Hygienic Monitoring (FIF SHM) in 2015-2016 quality of drinking water was monitored as per its chemical structure in $85 \mathrm{RF}$ regions; in $82 \mathrm{RF}$ regions in 2014 and 2015.

In 2018 and 2017 centers for hygiene and epidemiology located in RF regions and other certified laboratories submitted data to the FIF SHM on 84 chemicals contained in water; in 2016, on 79 chemicals; in 2015, on 105 chemicals; in 2014, on 107 chemicals.

In the RF in 2018 more than 5\% water samples deviated from hygienic standards as per contents of the following chemicals: bromine (75.0\% non-conforming samples), silicon $(21.0 \%)$, lithium $(17.5 \%)$, iron $(13.0 \%)$, sodium $(12.0 \%)$, chloroform $(11.2 \%)$, magnesium $(10.2 \%)$, boron $(8.1 \%)$, manganese $(6.70 \%)$, strontium $(5.94 \%)$, sulfides and hydrogen sulfide $(5.49 \%)$.

Over 2014-2018 the highest share of samples deviating from hygienic standards as per the $1^{\text {st }}$ hazard category chemicals contained chloroform (from 7.89 to $11.3 \%$ samples). Other hazardous chemicals included (in a descending 
order) bromdichloromethane $(0.21-1.60 \%$ samples with contends higher than MPC), trichloroethylene (0.58-3.21\%), 1,2-dichloroethane (0.08-0.80\%), dichloromethane $(0.72-5.59 \%)$, tetrachloromethane $(0.12-0.83 \%)$, tetrachloroethylene $(0.03-0.43 \%)$, and arsenic $(0.10-0.33 \%)$. The highest number of drinking water samples not conforming to sanitary-epidemiologic requirements as per contents of the $2^{\text {nd }}$ hazard category chemicals contained bromine $(75.0 \%)$. A share of samples with silicon contents deviating from hygienic standards was a bit lower (20.54-24.9\% samples with silicon contents higher than MPC), followed by lithium (14.9-38.1\%), sodium (11.6-15.0\%), boron $(8.05-8.69 \%)$, strontium $(3.50-6.01 \%)$, and some other chemicals. Priority chemicals that belonged to the $3^{\text {rd }}$ hazard category included iron (12.1-15.1\% samples with its concentration higher than MPC), magnesium (7.35$10.15 \%)$, manganese $(6.28-7.10 \%)$, aluminum $(2.44-3.60 \%)$, nitrates $(1.24-1.64 \%)$, and copper $(0.003-0.03 \%)$; the $4^{\text {th }}$ hazard category chemicals includes sulfides and hydrogen sulfide (1.41-5.49\% samples with their concentrations being higher than MPC), ammonia and ammonia-ion (1.42-1.89\%), sulfates (1.34-1.74\%), chlorides (1.26-2.09\%), and phenol $(0.00-0.25 \%)$.

Comparative analysis revealed that basically contents of chemicals belonging to the $3^{\text {rd }}$ and $4^{\text {th }}$ hazard category in drinking water were under control in the RF regions within social and hygienic monitoring activities. In 2014-2018 more than 620.9 thousand drinking water samples were analyzed as per iron contents (the $3^{\text {rd }}$ hazard category); more than 421.5 thousand samples, as per nitrates contents (the $3^{\text {rd }}$ category); more than 381.1 samples, as per ammonia contents (the $4^{\text {th }}$ category); more than 348.5 thousand samples, as per chlorides contents (the $4^{\text {th }}$ category), etc.

At the same time, overall number of water samples taken to detect chemicals belonging to the1st and $2^{\text {nd }}$ hazard categories in them was significantly lower. Thus, to detect chloroform (the $1^{\text {st }}$ category) in drinking water, experts took more than 56.4 thousand samples; tetrachloromethane (the $1^{\text {st }}$ category), more than 28.2 thousand samples; 1,2dichloroethane (the $1^{\text {st }}$ category), more than 5.46 thousand samples; bromdichloromethane (the $1^{\text {st }}$ category), more than 16.4 thousand samples; etc.

We established that in 2014-2018 all the RF regions $(100 \%)$ performed monitoring over iron contents (the $3^{\text {rd }}$ hazard category) in drinking water; 93.9-95.3\% RF regions monitored nitrates 9 the $3^{\text {rd }}$ hazard category); $88.2-92.7 \%$, chlorides (the $4^{\text {th }}$ hazard category); $88.2-91.5 \%$, ammonia (the $4^{\text {th }}$ hazard category); 87.1-93.9\%, manganese (the $3^{\text {rd }}$ hazard category); $84.7-90.2 \%$, sulfates (the $4^{\text {th }}$ hazard category).

But still only some regions in the RF performed control over priority chemicals belonging to the $1^{\text {st }}$ hazard category in drinking water; dichloromethane was under control in 3.5\% - 7.3\% RF regions; 1,2dichloroethane, 9.4-11.8\%; tetrachloroethylene, $12.9-14.6 \%$; trichloroethylene, $10.6 \%$ $15.9 \%$; bromdichloromethane, $16.5-21.2 \%$; tetrachloromethane, 25.9-28.0\%; chloroform, 45.1-52.9\%; arsenic, 63.5-70.7\% of all the RF regions.

We should note that contents of priority chemical contaminants in drinking water were significantly higher in some RF regions than in the country on average and it caused elevated health risks there. Thus, for example, in 2018 in Rostov region bromdichloromethane contents were higher than hygienic standards in $41.4 \%$ drinking water samples. In Primorye in 2017 and 2018 all the $100 \%$ water samples didn't conform to sanitary requirements as per trichloroethylene contents. In 2018 chloroform concentrations in drinking water were higher than hygienic standards in $83.3 \%$ samples taken in Volgograd region; in $37.9 \%$ samples taken in Kirov region; in $36.3 \%$ samples taken in Karelia; etc.

Increased chemicals concentrations in drinking water can have adverse effects on the urogenital, musculoskeletal, endocrine, nervous, and cardiovascular system, digestive organs, skin, blood system, and the immune system; they can also exert negative influence on 
development processes in a body and the reproductive system ${ }^{15}$.

There was a decrease in additional death cases that were probably caused by drinking water contamination in the RF over 2014-2018 (by $8.3 \%$ among the overall population). This parameter went down by $1.76 \%$ in 2018 against 2016. In 2018 in the RF in general a number of additional death cases caused by any reason associated with poor quality of drinking water from centralized water supply systems probabilistically amounted to 10.93 cases per 100 thousand people or $0.9 \%$ of all the death cases.

In 2018 in the RF in general a number of additional diseases caused by drinking water contamination probabilistically amounted to $1,201.3$ cases per 100 thousand people $(1.5 \%$ of the overall incidence among the RF population), and 437.5 cases per 100 thousand children $(1.3 \%$ of the overall incidence among children). There was a slight decrease in a number of additional disease cases caused by drinking water contamination; the parameter fell by $2.05 \%$ against 2014 among the overall RF population.

Chlorine and chlorinated organic compounds, ammonia and ammonia-ion, iron, manganese, arsenic, nickel, and copper in their concentrations in drinking water higher than MPC as well as microbiological contamination of drinking water make the greatest contribution into occurrence of additional incidence cases caused by poor quality of dirking water taken from centralized water supply systems.

In $201891.4 \%$ of the overall country population was provided with drinking water conforming to safety requirements and it was by $2.0 \%$ higher than in $2014^{16}$.

There was a preliminary assessment aimed at determining a share of urban population in the RF who were provided with drink- ing water from centralized water supply systems with its quality conforming to all the requirements fixed in the methodical guidelines issued in 2019; the assessment revealed that a target figure fixed by in the Federal Project "Pure water" was already reached in 2018 in 6 RF regions including Moscow city (99.63\%), Saint Petersburg (99.99\%), KabardinoBalkaria (100\%), Stavropol region (99.99\%), Kamchatka (99.95\%), and Astrakhan region $(99.01 \%)^{17}$.

According to preliminary assessments, in 2018 another target figure for 2024 fixed in the Federal Project "Pure water" $(90.8 \%$ of the overall country population provided with qualitative drinking water from centralized water supply systems) was achieved in $7 \mathrm{RF}$ regions including Saint Petersburg (100\%), Moscow city (99.6\%), Kamchatka (98.7\%), Sevastopol (97.4\%), Stavropol region (95,5\%), North Ossetia - Alania (94.1\%), and Lipetsk region $(90.8 \%)$.

We applied clusterization as per a set of 8 parameters including "changes in a share $(\%)$ of population provided with qualitative drinking water from centralized water supply systems" as a result, all $85 \mathrm{RF}$ regions were divided into 3 clusters (3 types of territory) (Figure and Table).

The first cluster included 44 regions in the RF (Figure). All these regions had similar trends such as an increase (by $3.08 \%$ on average) in a share of population provided with qualitative drinking water from centralized water supply systems, a considerable decrease in a number of additional incidence cases (by 4.7 cases per 1,000 people) and death cases (by 0.04 cases per 1,000 people) among population caused by poor quality of drinking water, and less frequently detected violations of Clause 19, 52-FZ, by economic entities dealing with water collection and purification, and

\footnotetext{
${ }^{15}$ On sanitary-epidemiologic welfare of the population in the Russian Federation in 2018: The state report. - M.: The Federal Service for Surveillance over Consumer Rights Protection and Human Well-being, 2019. - $254 \mathrm{p}$.

${ }^{16}$ On sanitary-epidemiologic welfare of the population in the Russian Federation in 2018: The state report. - M.: The Federal Service for Surveillance over Consumer Rights Protection and Human Well-being, 2019. - 254 p.

${ }^{17}$ MG 2.1.4.0143-19. Guidelines on how to assess improvements in quality of drinking water taken from centralized water supply systems / approved by the RF Chief Sanitary Inspector on March 27, 2019. - M.: The Federal Service for Surveillance over Consumer Rights Protection and Human Well-being, 2019. - 10 p.
} 


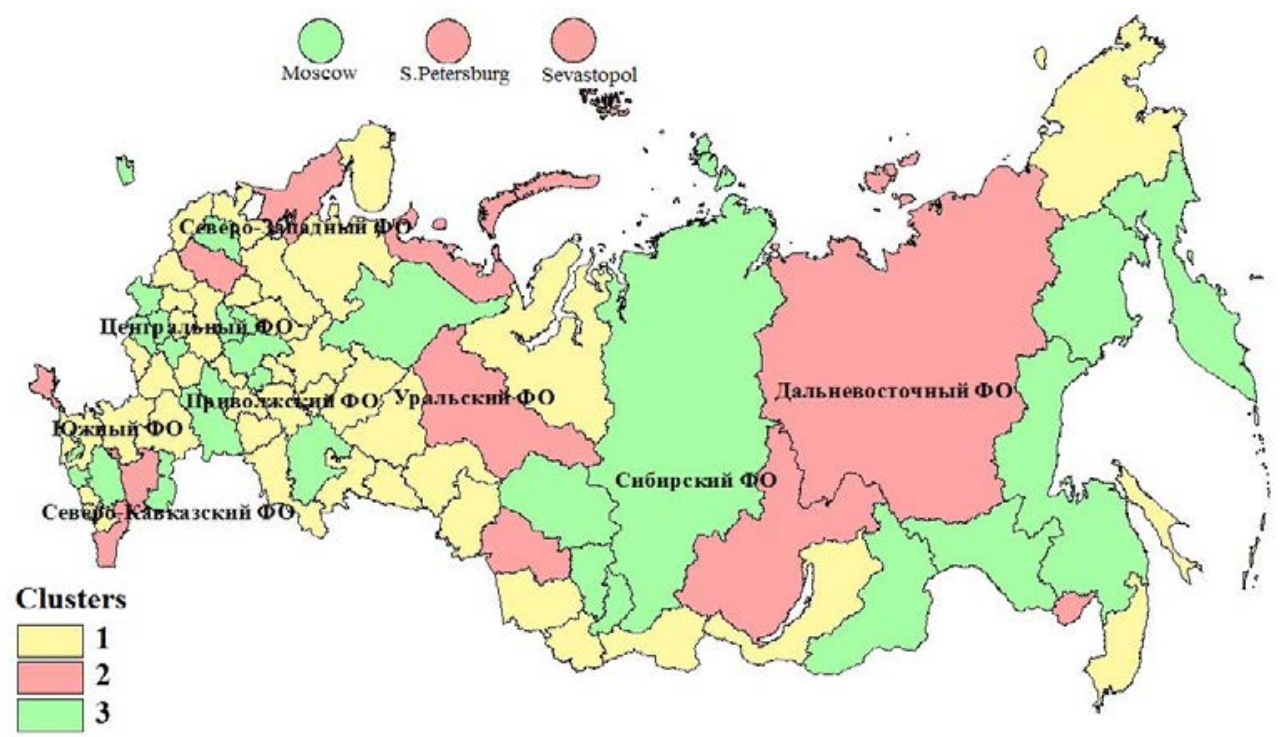

Figure. Results of cluster analysis: RF regions divided into 3 clusters as per a set of parameters

Table

Average parameter values in clusters

\begin{tabular}{|c|c|c|c|}
\hline \multirow[t]{2}{*}{ Parameters } & \multicolumn{3}{|c|}{$\begin{array}{l}\text { Average parameter } \\
\text { value in a cluster }\end{array}$} \\
\hline & 1 & 2 & 3 \\
\hline $\begin{array}{l}\text { Changes }(\Delta) \text { in a share of population provided with qualitative drinking water } \\
\text { from centralized water supply systems }(\%) \text { in } 2014-2018\end{array}$ & $3.08 \%$ & $-1.76 \%$ & $7.75 \%$ \\
\hline $\begin{array}{l}\text { Changes }(\Delta) \text { in incidence among population in a region caused by poor qual- } \\
\text { ity of drinking water (cases per } 1,000 \text { people) in } 2014-2018\end{array}$ & -4.70 & 11.37 & -0.19 \\
\hline $\begin{array}{l}\text { Changes }(\Delta) \text { in population mortality in a region caused by poor quality of } \\
\text { drinking water (cases per } 1,000 \text { people) in } 2014-2018\end{array}$ & -0.04 & 0.08 & -0.01 \\
\hline $\begin{array}{l}\text { Changes }(\Delta) \text { in frequency of violations concerning Clause 19,52-FZ, in a re- } \\
\text { gion in the sphere of water collection and purification }(\%) \text { in } 2014-2018\end{array}$ & $-0.44 \%$ & $-0.48 \%$ & $-0.20 \%$ \\
\hline $\begin{array}{l}\text { Changes }(\Delta) \text { in frequency of violations concerning Clause } 19,52-\mathrm{FZ} \text {, in a re- } \\
\text { gion in the sphere of water distribution }(\%) \text { in } 2014-2018\end{array}$ & $-0.20 \%$ & $-3.44 \%$ & $0.03 \%$ \\
\hline $\begin{array}{l}\text { Changes }(\Delta) \text { in incidence among population in a region caused by poor qual- } \\
\text { ity of drinking water and prevented by Rospotrebnadzor activities (cases per } \\
1,000 \text { people) in } 2014-2018\end{array}$ & -1.48 & -1.37 & 9.32 \\
\hline $\begin{array}{l}\text { Changes }(\Delta) \text { in mortality among population in a region caused by poor quality } \\
\text { of drinking water and prevented by Rospotrebnadzor activities (cases per } \\
1,000 \text { people) in } 2014-2018\end{array}$ & -0.02 & -0.05 & 0.09 \\
\hline $\begin{array}{l}\text { A ratio of gross regional product per capita in a RF region in } 2017 \text { to the } \\
\text { same parameter in } 2014 \text { (inflation taken into account), times }\end{array}$ & 0.92 & 1.07 & 0.96 \\
\hline
\end{tabular}

water distribution (by $0.44 \%$ and $0.20 \%$ respectively, Table). Activities performed by Rospotrebnadzor in the regions from the first cluster and aimed at preventing and reducing population incidence and mortality caused by poor quality of drinking water resulted in a decrease in these parameters, by $1.48 \%$ and $0.02 \%$ accordingly. Gross regional product per capita decreased in these regions over the analyzed period (by 0.92 times, Table).

Overall, these regions have quite favorable trends as regards a growing share of population provided with qualitative drinking water and declining incidence and mortality among population caused by poor quality of drinking water; however, activities performed 
by Rospotrebnadzor in these regions and aimed at preventing drinking water contamination and reducing health disorders caused by such contamination are becoming less efficient.

Besides, average cluster efficiency of Rospotrebnadzor activities (as per prevented GRP losses caused by drinking water quality) was the lowest among all three clusters in 2018 and amounted to 40.71 rubles per 1 spent ruble (average value for the country in general is 58.47 rubles per 1 spent ruble). The highest efficiency in this cluster was achieved in the following regions (in the descending order): Tyumen region, Perm region, and Tula region (127.93-115.29 rubles per 1 spent ruble).

The situation in these regions requires systematic work on increasing efficiency of Rospotrebnadzor activities aimed at improving drinking water quality including those based on the risk-oriented approach.

The second cluster included 13 regions: Saint Petersburg, Jewish Autonomous Area, Irkutsk region, Nenets Autonomous Area, Novosibirsk region, Dagestan, Kalmykia, Karelia, Yakutia, Tver' region, Khanty-Mansi Autonomous Area, Crimea, and Sevastopol (Figure).

There was the greatest spread of average parameter values in this cluster (Table): a decrease in a share of population provided with qualitative drinking water from centralized water supply systems $(-1.76 \%)$; a growth in mortality $(+0.08$ cases per 1,000 people) and incidence $(+11.37$ cases per 1,000 people) among population caused by poor quality of drinking water; less frequently detected violations of Clause 19, 52-FL, by economic entities dealing with water collection and purification $(-0.48 \%)$ and water distribution $(-3.44 \%)$; a decrease in number of deaths and incidence cases caused by poor quality of drinking water and prevented by Rospotrebnadzor activities (by 1.37 cases per 1,000 people and by 0.05 cases per 1,000 people, accordingly); an insignificant growth in gross regional product per capita in 2017 against 2014 (by 1.07 times).

Average cluster efficiency of activities performed by Rospotrebnadzor in 2018 was higher in the $2^{\text {nd }}$ cluster than in the $1^{\text {st }}$ one, 48.09 rubles per 1 spent ruble, but still it was lower than in the country on average. The highest efficiency in this cluster was achieved in 2018 in the following regions (in the descending order): Saint Petersburg, KhantyMansi Autonomous Area, and Sevastopol (116.02-77.75 rubles per 1 spent ruble).

So, the second cluster regions require developing and implementing certain measures aimed at reducing health disorders caused by poor quality of drinking water, wider implementation of the risk-oriented approach and an increase in efficiency of Rospotrebnadzor activities.

The third cluster included 28 regions where a share of population provided with qualitative drinking water from centralized water supply systems grew the most rapidly.

Besides, all the regions in the third cluster had a certain decrease in population mortality and incidence caused by poor quality of drinking water $(-0.01$ cases per 1,000 people and 0.19 cases per 1,000 people, respectively).

Also in these regions there was a slight decrease in frequency of violations by economic entities dealing with water collection and purification $(-0.20 \%)$ and a slight growth in the parameter in the sphere of water distribution $(+0.03 \%)$ (Table).

RF regions from the $3^{\text {rd }}$ cluster had a slight decrease in their gross regional product per capita in 2017 against 2014 (by 0.96 times).

Activities performed by Rospotrebnadzor aimed at preventing mortality and incidence caused by poor quality of drinking water were the most efficient in these regions $(+0.09$ cases per 1,000 people and +9.32 cases per 1,000 people, respectively).

Average cluster efficiency of activities performed by Rospotrebnadzor in 2018 was the highest in this cluster among all three, $60.62 \mathrm{ru}-$ bles per 1 spent ruble, and it was close to its average value in the country (58.47 rubles per 1 spent ruble). The highest efficiency in this cluster was achieved in 2018 in the following regions (in the descending order): Moscow city, Kemerovo region, Amur region, and Orel region (194.47-100.20 rubles per 1 spent ruble).

Overall, regions in the third cluster tend to have the highest share of population pro- 
vided with qualitative drinking water; steadily low incidence and mortality among population caused by poor quality of drinking water; high efficiency and productivity of activities by Rospotrebnadzor aimed at preventing such health disorders among population (60.62 rubles per 1 spent ruble in the cluster on average); and a slight decrease in the gross regional product in 2017 against 2014.

\section{Conclusions and recommendations:}

1. The research has revealed that certain chemicals can be considered priority ones in the RF as their contents in drinking water were higher than hygienic standards in more than 5\% samples; they are bromine, silicon, lithium, iron, sodium, magnesium, boron, manganese, strontium, sulfides and hydrogen sulfide, and some other compounds.

2. Within social and hygienic monitoring, it is necessary to performed stricter control over contents of chemicals that belong to the $1^{\text {st }}$ hazard category including chlorinated organic compounds (chloroform, bromdichloromethane, trichloroethylene, 1,2-dichloroethane, dichloromethane, tetrachloromethane, tetrachloroethylene etc.), and arsenic.

3. Chlorine and chlorinated organic compounds, ammonia and ammonia-ion, iron, manganese, arsenic, nickel, and copper in their concentrations in drinking water higher than MPC as well as microbiological contamination of drinking water make the greatest contribution into occurrence of additional incidence cases caused by poor quality of dirking water taken from centralized water supply systems.

4. Over the last 5 years (2014-2018) there has been a steady growth in a share of RF population provided with safe drinking water from centralized drinking water supply systems. In $201891.4 \%$ of the total country population was provided with drinking water that conformed to safety requirements and it was by $2.0 \%$ higher than in 2014 .

5. All the RF regions were divided into three clusters (three types of territories) as per results of cluster analysis performed with a set of parameters that characterized efficiency of Rospotrebnadzor activities concerning objects under surveillance dealing with water collection, purification, and distribution:

- regions in the first cluster had quite favorable trends such as a growing share of population provided with qualitative drinking water, falling incidence and mortality among population caused by poor quality of drinking water; however, efficiency of Rospotrebnadzor activities performed in them decreased over 2014-2018. It is necessary to systematically increase efficiency of activities performed by Rospotrebnadzor and aimed at improving drinking water quality;

- regions in the second cluster had an increase in mortality and incidence among population caused by poor quality of drinking water, Rospotrebnadzor activities aimed at reducing them were not efficient, but there was a rapid growth in gross regional product per capita in those regions. For these regions, it is necessary to develop and implement urgent measures aimed at preventing health disorders caused by poor quality of drinking water, wider implementation of the risk-oriented approach, and increasing efficiency of Rospotrebnadzor activities;

- activities performed by Rospotrebnadzor in regions in the third cluster were the most productive and efficient; a share of population provided with qualitative drinking water was also the highest there; population incidence and mortality caused by poor quality of drinking water were steadily low in those regions; activities performed by Rospotrebnadzor and aimed at preventing health disorders caused by poor quality of drinking water were the most productive and cost-effective (60.62 rubles per 1 spent ruble in the cluster on average); there was a slight decrease in the gross regional product in those regions in 2017 against 2014.

6. In 2018 efficiency of Rospotrebnadzor activities as per prevented GRP losses caused by drinking water quality amounted to 58.47 rubles per 1 spent ruble in the country on average. The highest cost efficiency was detected in the $3^{\text {rd }}$ cluster; and the lowest one, in the $1^{\text {st }}$ cluster (40.71 rubles per 1 spent ruble). 
7. It is necessary to develop regional action plans aimed at maintaining provision of population with qualitative drinking water that has already been reached; improving control and surveillance activities with the risk-oriented approach being widely implemented; setting goals to achieve target figures fixed in national projects and federal programs (in particular, The Federal Project "Pure water" and the National
Project "Ecology"). All this should be done taking into account regional peculiarities and cluster analysis results that allowed dividing all the RF regions into three different clusters.

Funding. The research was not granted any sponsor support.

Conflict of interests. The authors state there is no any conflict of interests.

\section{References}

1. Rakhmanin Yu.A., Mel'tser A.V., Kiselev A.V., Erastova N.V. Hygienic substantiation of management decisions with the use of the integral assessment of drinking water on indices of chemical harmlessness and epidemiological safety. Gigiena i sanitariya, 2017, vol. 96, no. 4, pp. 302-305.

2. Kuznetsov K.S., Belkina A.A., Yadrova A.A. Assessment of the quality of drinking water supplied from centralized water supply systems in Moscow (Russia). Mezhdunarodnyi studencheskii nauchnyi vestnik, 2018, vol. 4, no. 4, pp. 681-685.

3. Kiku P.F., Kislitsyna L.V., Bogdanova V.D., Sabirova K.M. Hygienic evaluation of the quality of drinking water and risks for the health of the population of the primorye territory. Gigiena $i$ sanitariya, 2019, vol. 98, no. 1, pp. 94-101.

4. Luzhetsky K.P., Ustinova O.Yu., Kleyn S.V., Vandysheva A.Yu., Vekovshinina S.A. Features of the development of metabolic violations in children population, residing in conditions of chronic peroral exposure of chlororganic compounds. Zdorov'e naseleniya i sreda obitaniya, 2018, vol. 303, no. 6, pp. $40-44$.

5. Chetverkina K.V., Kleyn S.V., Chigvintsev V.M. Hygienic assessment of dynamics of chloroform exposition in perm region and it's impact on causing diseases of the blood, blood-forming organs and certain disorders involving immune mechanism among children. Gigiena i sanitariya, 2018, vol. 97, no. 1 , pp. 29-34.

6. Averin A.N., Lyakhov V.P., Evtushenko S.A., Nuvakhov T.A. Discusses the importance of a national project in the field of the environment for the environmental well-being of the Russian people. Nauka i obrazovanie: khozyaistvo i ekonomika; predprinimatel'stvo; pravo i upravlenie, 2019, vol. 107, no. 4, pp. 131-134.

7. Popova A.Yu., Zaitseva N.V., May I.V. Experience of methodological support and practical implementation of the risk-oriented model of sanitary-epidemiological surveillance in 2014-2017. Gigiena $i$ sanitariya, 2018, vol. 97, no. 1, pp. 5-9.

8. Zaitseva N.V., Kir'yanov D.A., May I.V., Shur P.Z., Tsinker M.Yu. Conceptual assignment and experience of the task solution for optimization of supervisory activities in the field of sanitary and epidemiological welfare of the population. Gigiena $i$ sanitariya, 2017, vol. 96, no. 1, pp. 10-15.

9. Tulakin A.V., Plitman S.I., Ampleeva G.P., Pivneva O.S. Risk-orientirovannyi nadzor kak osnova obespecheniya bezopasnosti pit'evoi vody: Problemy i vozmozhnosti [Risk-oriented surveillance as a basis for providing drinking water safety: Issues and opportunities]. Nauchno-prakticheskii zhurnal, 2018, vol. 21, no. 3, pp. 28-31.

10. Nefedova E.D., Khyamyalyainen M.M., Kovzharovskaya I.B., Shevchik G.V. Risk-oriented approach to the arrangement of drinking water quality control. Vodosnabzhenie i sanitarnaya tekhnika, 2018, no. 3, pp. 5-9.

11. Zaitseva N.V., May I.V., Kir'yanov D.A., Sboev A.S., Andreeva E.E. Conceptual and methodological aspects of improving the effectiveness of control and supervisory activities based on hazard and risk assessment and estimation of harm to health of the population. Zdorov'e naseleniya $i$ sreda obitaniya, 2014, no. 12, pp. 4-7.

12. Kleyn S.V., Zaitseva N.V., May I.V., Kir'yanov D.A. Analiz struktury i prostranstvennogo raspredeleniya potentsial'nykh riskov prichineniya vreda zdorov'yu pri osushchestvlenii khozyaistvennoi deyatel'nosti v sfere «Sbor i ochistka vody» [Analysis of structure and spatial distribution of potential 
health risks caused by economic activities involving water intake and purification]. Aktual'nye voprosy analiza riska pri obespechenii sanitarno-epidemiologicheskogo blagopoluchiya naseleniya i zashchity prav potrebitelei: materialy VIII Vserossiiskoi nauchno-prakticheskoi konferentsii s mezhdunarodnym uchastiem. In: A.Yu. Popova, N.V. Zaitseva eds., Perm, 2018, pp. 154-161.

13. Sboev A.S., Vekovshinina S.A. To the problem of the assessment and increase of the effectiveness of control-supervisory arrangements providing Perm region population with clear drinking water. Zdorov'e sem'i-21 vek, 2015, vol. 1, no. 1, pp. 116-135.

14. Zaitseva N.V., May I.V., Shur P.Z., Kir'yanov D.A. Methodological approaches for assessement performance and economical efficiency of the risk-oriented control and supervision of the Federal service on customers' rights protection and human well-being surveillance (Rospotrebnadzor). Health Risk Analysis, 2014, no. 1, pp. 4-13. DOI: 10.21668/health.risk/2014.1.01.eng

15. Selyunina S.V., Zaitseva N.V., Tsinker M.Yu. Calculation of economic loss from population mortality associated with the negative effects of environmental factors on the territories of subjects of the Russian Federation with placed objects for storage and destruction of chemical weapons. Zdorov'e naseleniya i sreda obitaniya, 2015, vol. 270, no. 9, pp. 15-20.

16. Selyunina S.V., Zaitseva N.V. Assessment of excess mortality and morbidity of the Kirov region as the main indicators characterizing the health damage from pollution. Zdorov'e naseleniya $i$ sreda obitaniya, 2015, vol. 262, no. 1, pp. 13-16.

17. Popova A.Yu., Zaitseva N.V., May I.V., Kir'yanov D.A. Methodological approaches to the calculation of actual and prevented as a result of the control and supervisory activities, medicaldemographic and economic 95 losses, associated with the negative impact of environmental factor. Gigiena i sanitariya, 2015, vol. 94, no 7, pp. 95-99.

18. Popova A.Yu., Bragina I.V., Zaitseva N.V., May I.V., Shur P.Z., Mitrokhin O.V., Goryaev D.V. On the scientific and methodological support of the assessment of the performance and effectiveness of the control and supervision activity of the Federal Service For Surveillance On Consumer Rights Protection And Human Wellbeing. Gigiena i sanitariya, 2017, vol. 96, no. 1, pp. 5-9.

19. Zaitseva N.V., May I.V., Kleyn S.V., Kir'yanov D.A. Methodological aspects and results of estimation of demographic loss associated with harmful influence of environment factors and preventive activities of Rospotrebnadzor in regions of the Russian Federation. Zdorov'e naseleniya $i$ sreda obitaniya, 2018, vol. 301, no. 4, pp. 15-20.

20. Zaitseva N.V., Kir'yanov D.A., Tsinker M.Yu., Kostarev V.G. Methodical approach to the investigation of reserves in the performance and management in the system of federal service for surveillance over consumer rights protection and human well-being (Rospotrebnadzor) as according to prevented health losses in the population of the Russian Federation. Gigiena i sanitariya, 2019, vol. 98, no. 2, pp. 125-134.

Zaitseva N.V., Sboev A.S., Kleyn S.V., Vekovshinina S.A. Drinking water quality: health risk factors and efficiency of control and surveillance activities by rospotrebnadzor. Health Risk Analysis, 2019, no. 2, pp. 44-55. DOI: 10.21668/health.risk/2019.2.05.eng

Received: 18.05.2019

Accepted: 19.06 .2019

Published: 30.06.2019 